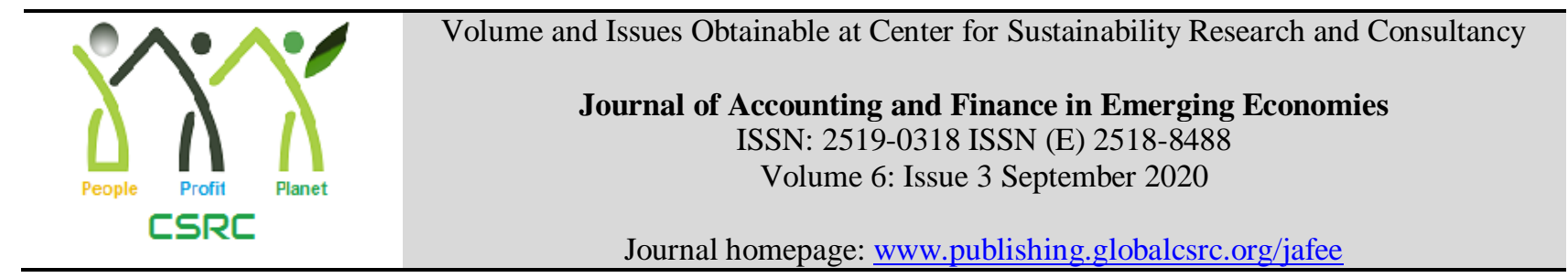

\title{
Identification of Stress Management Techniques used by Head Teachers in the Province of Punjab
}

\author{
${ }^{1}$ Misbah Malik, ${ }^{2}$ Ghulam Fatima, ${ }^{3}$ Rukhsana Bashir \\ ${ }^{1}$ Assistant Professor, Institute of Education and Research, University of the Punjab, Lahore, Pakistan, \\ misbahmalik@ue.edu.pk \\ ${ }^{2}$ Associate Professor, Institute of Education and Research, University of the Punjab, Lahore, Pakistan, \\ fatima.ier@pu.edu.pk \\ ${ }^{3}$ Assistant professor, Department of Special Education, University of the Punjab, Lahore, Pakistan, \\ rukhsana.dse@gmail.com
}

\begin{tabular}{l}
\hline ARTICLE DETAILS \\
\hline \\
\hline History \\
Revised format: August 2020 \\
Available Online: September \\
2020
\end{tabular}

\section{Keywords}

Stress management techniques,

Secondary School Head

Teachers, Punjab

JEL Classification

M40,M41

\section{ABSTRACT}

The basic purpose of this quantitative study was to identify the use of stress management techniques by head teachers of secondary schools in the province of the Punjab. All the head teachers of secondary schools in Punjab was the population of the study. A sample of 35 head teachers was selected through cluster sampling technique. A group of head teachers getting Promotion Linked Training (PLT) at Quaid e Azam Academy of Educational Development (QAED) was selected as cluster for data collection. A selfdeveloped and validated questionnaire was used for data collection. The questionnaire comprised statements related to use of different stress management techniques. Five point likert type scale was used to get responses on statements. Descriptive statistics including $t$-test and ANOVA were used for data analysis. Mean and standard deviation were identified to assess the use of different stress management techniques by head teachers. Results showed that highly used stress management strategies included: doing prayers, going out for some enjoyment, watching TV, setting goals for future and sleeping quietly. Least used strategies included; doing exercise, deep breathing, finding own mistake, reading books, writing diary, going to watch movie and going to specialist for consultation etc. Recommendations were made on the basis of these findings.

\section{OPEN ACCESS}

(C) 2020 The authors, under a Creative Commons Attribution-NonCommercial 4.0

Corresponding author's email address: misbahmalik@ue.edu.pk

Recommended citation: Malik, M., Fatima, G., \& Bashir, R. (2020). Identification of Stress Management Techniques used by Head Teachers in the Province of Punjab. Journal of Accounting and Finance in Emerging Economies, 6(3), 733-745

\section{Introduction}

Stress is a common element of daily life. Due to dealing with different people, situations, and circumstances, people feel themselves overwhelmed both physically and emotionally. It is common that people feel that they cannot deal with the stress they are experiencing or they have limited resources to deal with. Any situation or thought can make 
one stressful, frustrated, angry or anxious. It depends on ones' own perception about the situation and the technique to cope with the situation. Some situations may be stressful for one person but normal for the other one. One person's reaction towards the situation determines its impact, not only on his health but also on his life. Excessive stress can cause health problems. According to Chen (1998), stress can affect ability to perform a task at the highest level. The destructive properties of stress can influence negatively the quality and performance of one's life.

There are many effects of stress including high heart rate, fast breathing or seized breath, muscle stretching, detracting blood to the brain and other major muscles which cause digestion problems, hands/feet shivering, damaging reproductive organs, discharging of stress hormones (i.e. cortisol and adrenaline), causing the brain to be less thoughtful or more reactive, excessive perspiration, weaken immune system (Guglielmi \&Tatrow, 1998). Moreover they mentioned the consequences of stress as "tension, aches, neck/back/shoulder pain, tight jaw, sleeping problems, fatigue, loss of concentration, increasing learning problems, irregular or rapid heart rate, migraine, poor blood circulation, Raynaud Syndrome, high blood pressure, sexual dysfunction (in either sex), digestive problems, upset stomach, ulcers, colitis, hormone imbalances, reduction of immune system function, over reaction by immune system (allergies or autoimmune diseases worse), increased asthma activity, increased aging rate, anxiety, depression, substance abuse, poor habit control, over-eating, low energy, prone to accidents or mistakes, impaired communication and poor performance" (Guglielmi \& Tatrow, 1998).

As a matter of fact head teachers have profound effect on children's' lives. Along with supporting learning, they are also key mediators of developing, socializing, grooming their students to realize their goals and grow into sensible individuals. But, teaching profession has become highly stressful. No doubt it is one of the most successful occupations over the past few years all over the world, but it has become increasingly stressful.

Head teachers' stress not only impacts their teachers' well-being, health, job attitudes (e.g. "job satisfaction"), and retention but, it is also effects teachers' performance and their students' academic achievement. Head teachers are leaving their jobs due to high level of stress. It creates insecurity among teaching staff, students, and the parents. As a result these schools have to hire new head teachers who have less experience, which may be one of the major cause of students' low achievement. To control this phenomenon significant training is needed to make school systems effective and efficient.

This research paper examined the factors of head teachers' stress, highlighted programs and policies that can control head teachers' stress and enhance their performance and well-being. Four main sources of head teachers' stress are; "First in School Organizations, it includes principal leadership; school climate and school environment; secondly, Job requirements including high-level testing, behavioral problems of students, and over conscious and highly demanding parents; thirdly, highly professional demands that reduce a head teacher's independence and decision-making and fourth, head teachers' emotional and social status that are very much linked with their personal and social life.

The negative consequences of head teachers' stress affect their teachers' mental and physical health. Most of the teachers reported feeling of high stress that continues to several days a week. According to a national survey in USA, forty-six percent of head teachers reported high level of routine stress within the school timings which is among the highest rate of routine stress among all the occupations, due to which they were tied with nurses, this ratio is higher than physicians. High level of stress may be one of the major cause of low new head teachers' retention.

Head teacher stress is associated with poor performance of teachers and poor student outcomes. According to a longitudinal study, the teachers who have reported greater stress and show more indications of unhappiness create less conducive classroom environments which result in poor academic performance of students. The teachers who report more burnout have been facing more behavior problems in their classes. When students find their teachers highly stressed, they begin to have problem in social adjustment and academic performance.

According to Cox (1978) environmental factors of teachers' stress may be divided into three broad areas; "factors intrinsic to teaching, cognitive factors affecting the individual vulnerability of teachers and systemic factors operating at the institutional and political level". Systemic denotes a large cluster of organizational aspects that are not basic 
component of teaching, but are related to the organizational culture of any of specific institution or broader education context and political intervening. According to Travers and Cooper (1997) the greatest sources of stress for head teachers included: "lack of government support", "lack of information about changes", "constant change" and "the demands of the National Curriculum" etc. Jennings and Kennedy (1996) extended these factors to "systemic factors" embedded into the nature of individual organizations.

To ensure increased access and quality of primary and secondary schooling, a great demand has been laid on head teachers, especially after the introduction of "Free Primary Education" in 2003. Pressure on head teachers has been increased due to which head teachers are working under stress, in congested classrooms and decrepit buildings without the necessary learning facilities. Keeping in view all the negative effects of head teachers' stress this study was conducted to identify underlying stress factors inside and outside school.

According to Kyriacou (2001), each head teacher has different stress factors which are unique to him/ her, most of the time depends on the nature of interaction between their personality, values, skills, and circumstances. Many environmental factors and personality traits can affect perception and reactions in stressful situations which as a result affect teachers' emotional behaviors and life quality. This background provides an overview of stress factors and its consequences among the head teachers. There is a huge responsibility upon secondary school teachers because secondary school is considered as one of the important and terminal stage of students' life. So, head teachers have to face many pressures and other social factors which cause stress among heads. There is scarcity of research which can provide stress management techniques used by head in secondary schools. It leaves the canvas incomplete, so on the basis of this background present study was design to find out the stress management techniques used by heads of secondary schools in the province of Punjab.

\section{Research Objectives}

The general objective of the study was to find the causes of stress among head teachers of public secondary schools in the province of Punjab. However, the study specifically aimed to:

1. Identify the stress management techniques used by head teachers in Punjab.

2. Identify the difference in stress management techniques used by male and female head teachers.

3. Identify the difference in stress management techniques used by head teachers in urban and rural areas.

4. Identify the difference in stress management techniques of head teachers on the basis of their experience.

5. Find out the difference in stress management techniques of head teachers on the basis of their qualification.

6. Explore the difference in stress management techniques of head teachers on the basis of their districts.

\section{Hypotheses}

The following hypotheses were formulated for the study:

1. There is significant difference between stress management techniques used by male and female head teachers.

2. There is significant difference between stress management techniques used by rural and urban areas' head teachers.

3. There is significant difference among stress management techniques of head teacher's experience.

4. There is significant difference in stress management techniques of head teachers on the basis of their qualification.

5. There is significant difference in stress management techniques of head teachers on the basis of their districts.

\section{Methodology}

This section entails the details about population, the sample and sampling techniques, instrument development and validation, data collection and data analysis techniques. Following procedures were followed to conduct the study: 


\subsection{Population}

All the teachers of secondary schools in the district of Sahiwal, Multan, Muzaffargarh, Bahawalpur, and Faisalabad constituted the population of study.

\subsection{Sample and Sampling Technique}

Sample of the study was selected through simple random sampling technique. List of all the schools were obtained from district head quarter of each district and schools were selected through using table of random numbers. From each district, seven schools were selected to obtain data from head teachers. The sample consisted of 35 head teachers. Table 1 shows the details of all the variables of study in this research.

\section{Table 1: Descriptive Statistics of the Variables of the Study}

\begin{tabular}{llll}
\hline Variable & Category & Numbers & Total \\
Gender & Male & 12 & 35 \\
& Female & 23 & \\
\hline Age range & $38-55$ & & 35 \\
\hline Schools & High & 17 & 35 \\
& Higher Secondary & 18 & 35 \\
\hline Designation & 18 & 18 & 35 \\
\hline Area & 19 & 18 & \\
& Rural & 15 & \\
\hline \multirow{2}{*}{ Experience } & Urban & 20 & 35 \\
\hline & Less than 10 & 5 & \\
Districts & $10-20$ & 22 & \\
& More than 20 & 8 & \\
\hline & Multan & 5 & \\
& Faisalabad & 5 & \\
& Sahiwal & 5 & \\
& Mazaffargrah & 5 & \\
\hline
\end{tabular}




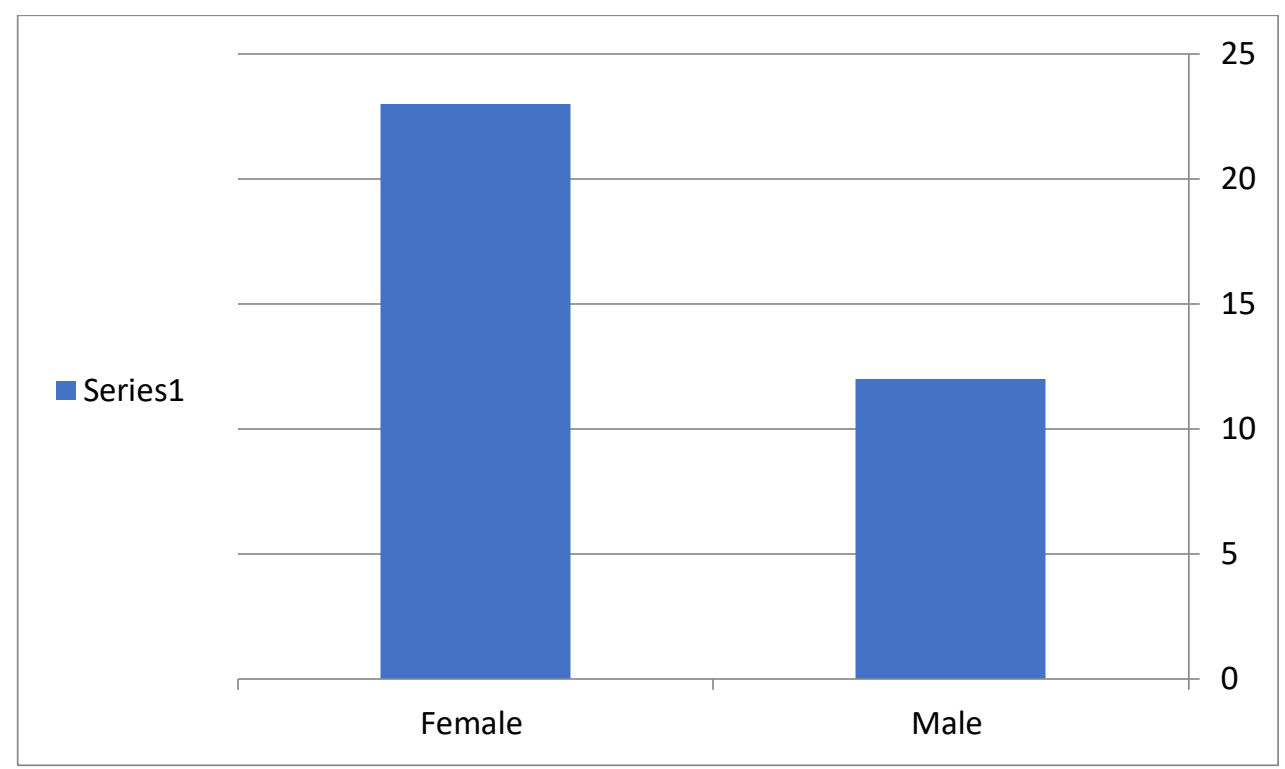

Figure 1: Graph of male and female head teachers

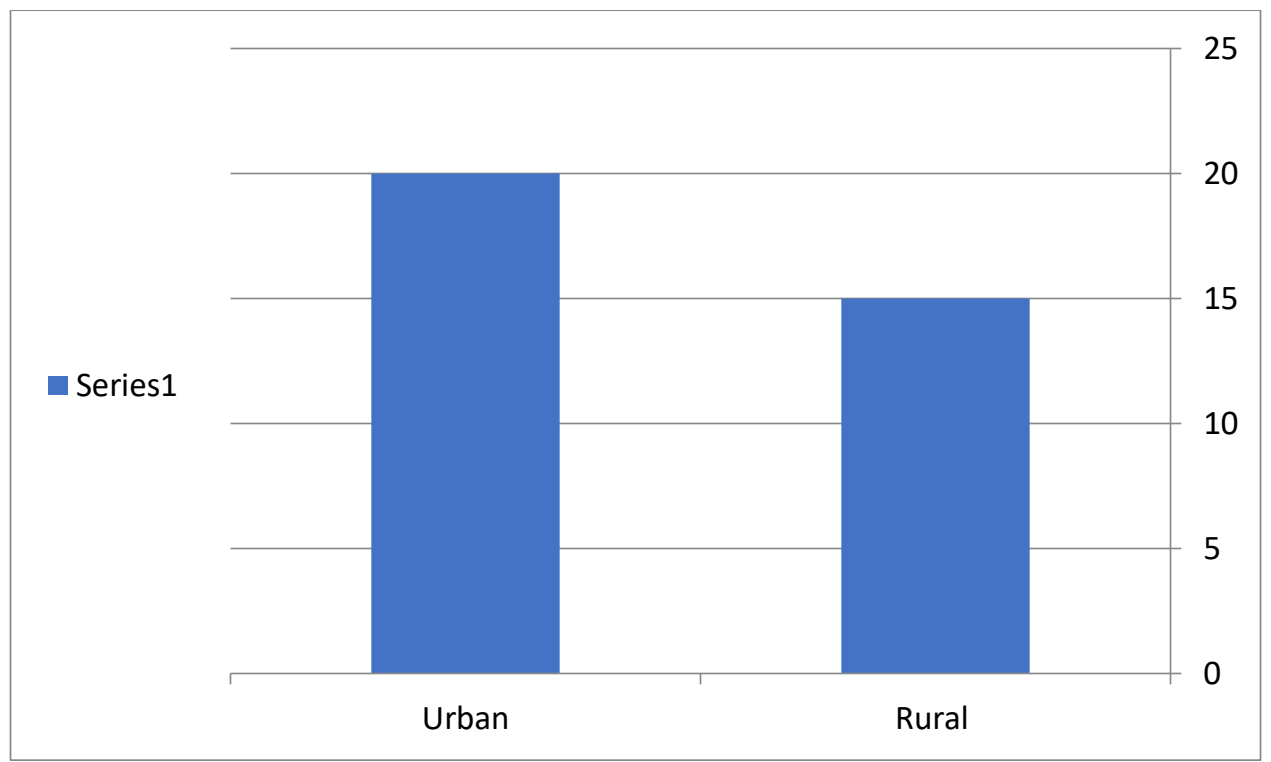

Figure 2: Graph of head teachers in urban and rural areas 


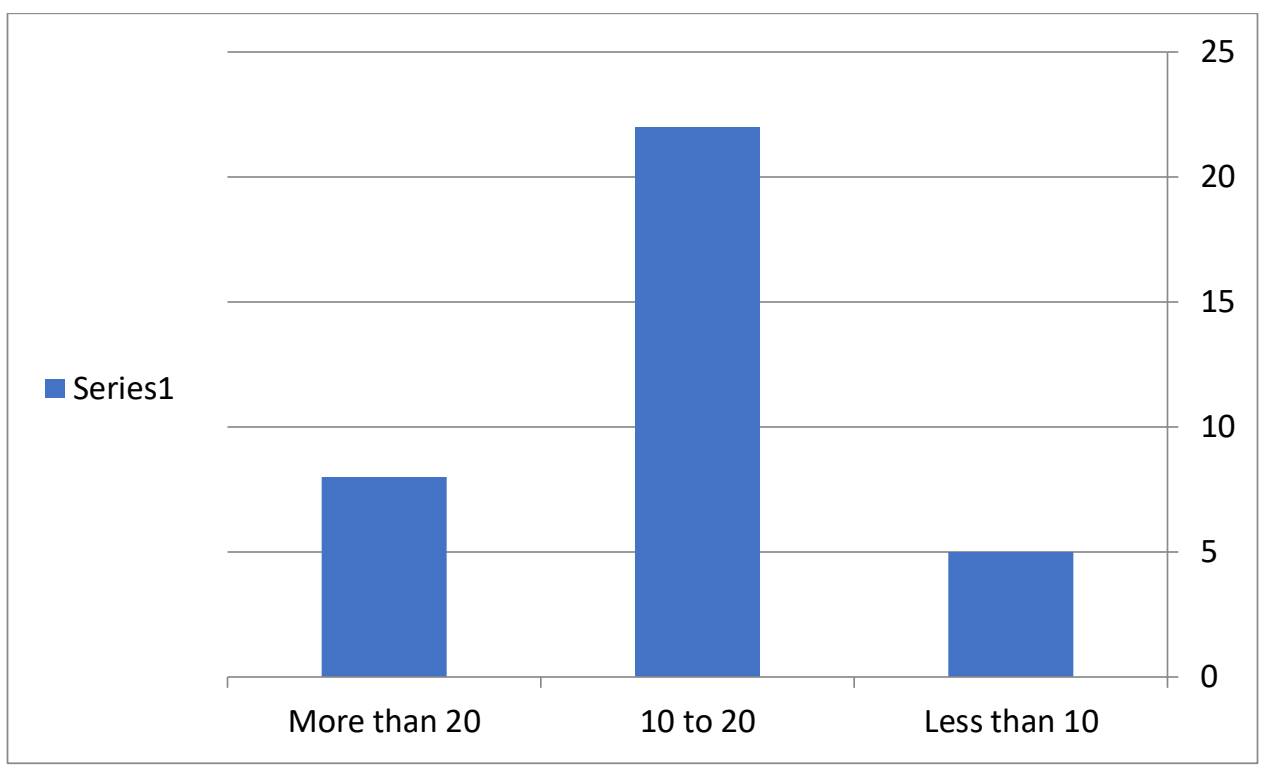

Figure 3: Graph for the teaching experience of head teachers

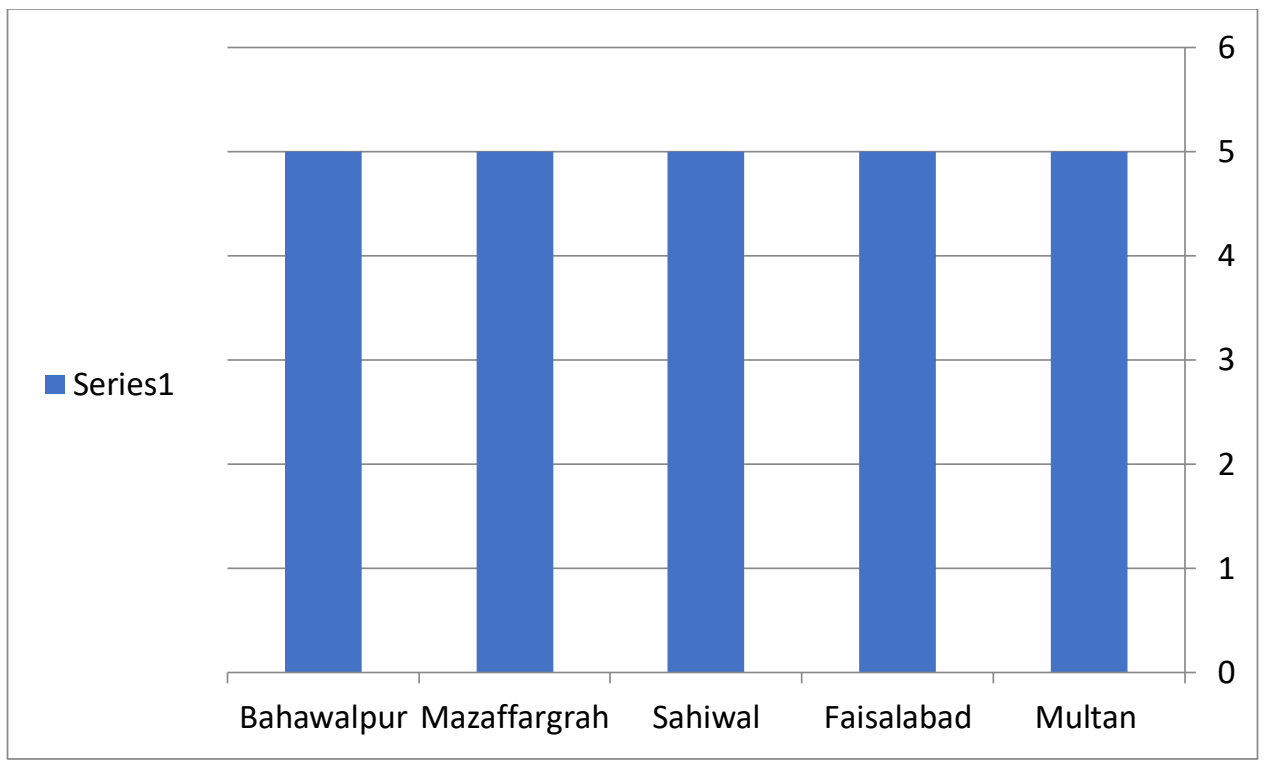

Figure 4: Graph showing district wise participation of teachers

\section{Instrument}

A self-developed and validated instrument was used to get head teachers' responses for their stress management techniques. Questionnaire comprised two sections: one to identify respondents' demographic information that is age, gender, school, district, experience, designation, academic and professional qualification and the second containing statements related to stress management techniques. The stress management techniques included: catharsis; sharing; going out; consultation; going to psychologist; taking medicine; scolding; meditation; exercise; breathe deeply; watching TV programs; finding out reasons; blaming oneself; writing diary and reading books etc.

\section{Data Analysis}

The data were analysed through employing suitable stats. Descriptive statistics were used to identify head teachers' stress management techniques according to different factor, $t$-test was applied to see mean difference in teachers' stress management techniques on the basis of gender, area, and designation. Analysis of Variance (ANOVA) test was applied to assess mean difference of head teachers' responses on the basis of district, school, years of experience, academic and professional qualification. The group of researchers personally collected data from the respondents. 
Table 2: Descriptive statistics of the questionnaire

\begin{tabular}{|c|c|c|c|}
\hline Sr.\# & Statements & Mean & $\begin{array}{l}\text { Std. } \\
\text { Deviation }\end{array}$ \\
\hline 1 & When I am in stress I do catharsis. & 3.5 & 0.24 \\
\hline 2 & When I feel stressed I share with my colleagues. & 3.56 & 0.44 \\
\hline 3 & When I am in stress I share with my family members. & 3.74 & 0.26 \\
\hline 4 & When I am in stress I share with my friends. & 3.88 & 0.12 \\
\hline 5 & When I am in stress I take help from my seniors. & 2.84 & 0.16 \\
\hline 6 & When I am in stress I go for shopping. & 3.54 & 0.46 \\
\hline 7 & When I am in stress I go to my relatives. & 3.7 & 0.3 \\
\hline 8 & When I am in stress I go to watch movie. & 1.76 & 0.24 \\
\hline 9 & When I am in stress I consult with my father/mother/elder. & 3.74 & 0.26 \\
\hline 10 & When I am in stress I go to consult with a specialist in the field. & 1.52 & 0.48 \\
\hline 11 & When I am in stress I consult with my friends. & 4.54 & 0.46 \\
\hline 12 & When I am in stress I consult with my relatives. & 2.32 & 0.68 \\
\hline 13 & In stress I become realistic. & 2.9 & 0.1 \\
\hline 14 & I set my goals in future when I am in stress. & 3.88 & 0.12 \\
\hline 15 & I go to psychologist when I am in stress. & 0.78 & 0.22 \\
\hline 16 & I follow psychologist's instructions to manage my stress. & 0.78 & 0.2 \\
\hline 17 & I take medicine when I am unable to overcome stress. & 2.8 & 0.2 \\
\hline 18 & I go for outing when I am in stress. & 3.9 & 0.1 \\
\hline 19 & I scold my juniors when I am in stress. & 3.66 & 0.34 \\
\hline 20 & I scold my subordinates when I am in stress & 3.6 & 0.4 \\
\hline 21 & I offer prayers when I am in stress. & 4.66 & 0.34 \\
\hline 22 & I ask others to pray for me when I am in stress. & 4.92 & 0.08 \\
\hline 23 & I do exercise when I am in stress. & 1.84 & 0.16 \\
\hline 24 & I go for some enjoyment when I am in stress. & 3.96 & 0.04 \\
\hline 25 & I use relaxing techniques when I am in stress. & 2.8 & 0.2 \\
\hline 26 & I breathe deeply to relax myself when I feel stressed. & 1.88 & 0.12 \\
\hline 27 & I sleep quietly when I am stressed. & 3.84 & 0.16 \\
\hline 28 & I watch my favorite TV program when I am in stress. & 4.00 & 0.22 \\
\hline 29 & I leave everything on Allah when I cannot manage my stress. & 3.88 & 0.12 \\
\hline 30 & I weep to manage my stress. & 4.24 & 0.18 \\
\hline 31 & I try to find out the reason of my stress to control it. & 2.74 & 0.26 \\
\hline 32 & I try to find out my mistake when I am in stress. & 3.78 & 0.22 \\
\hline 33 & I always accept my fault to manage my stress. & 1.8 & 0.2 \\
\hline 34 & I write diary to manage my stress. & 0.80 & 0.32 \\
\hline 35 & I read books when I am stressed. & 1.10 & 0.1 \\
\hline
\end{tabular}


Table 2 shows the mean and standard deviation of the statements to identify stress management techniques of head teachers.

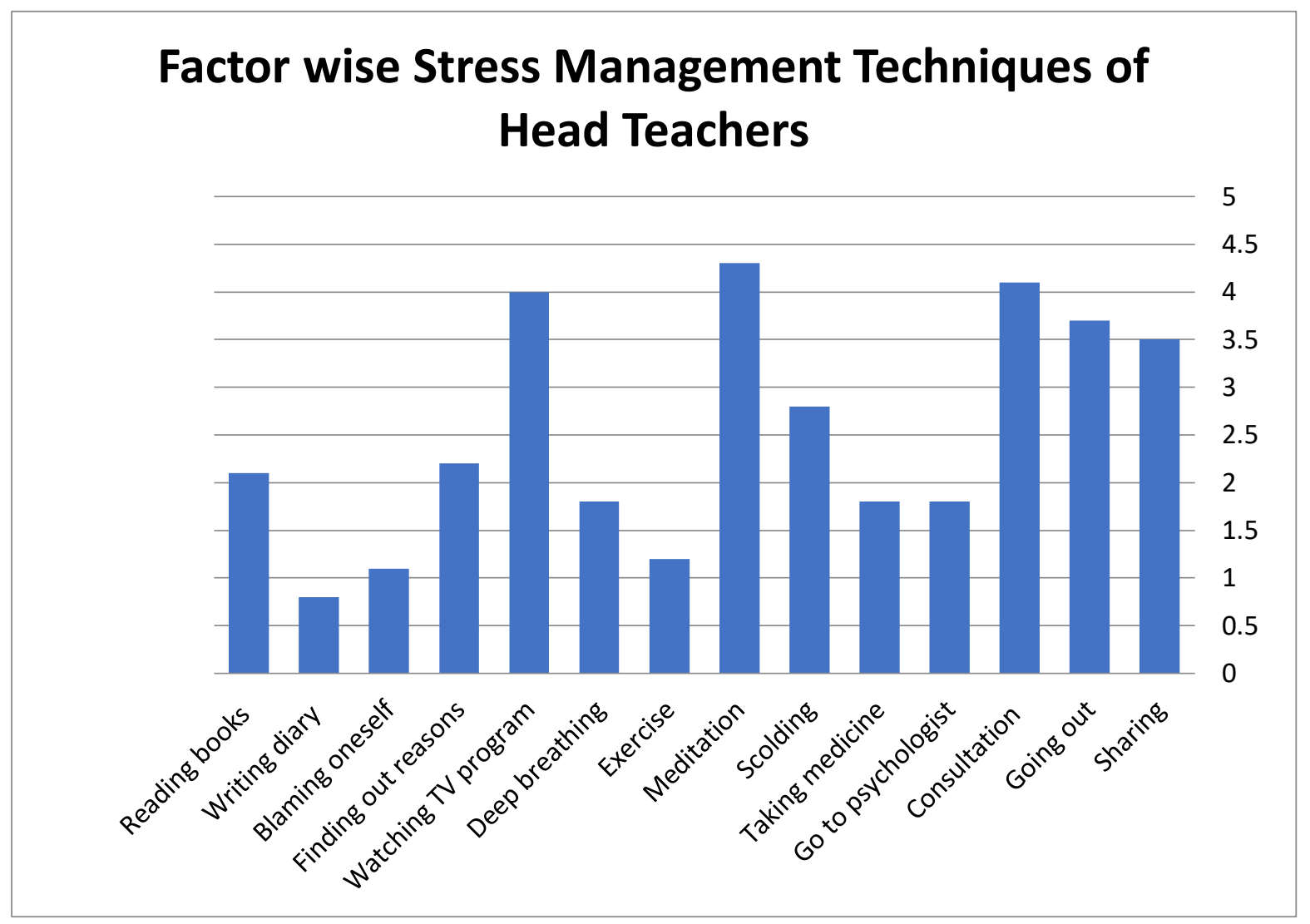

Figure 5: Graph of factor wise stress management techniques of head teachers in Punjab

Table 3: Independent Sample t-test to Identify Mean Difference in Male and Female Teachers' Stress Management Techniques

\begin{tabular}{llllll}
\hline Variables & $N$ & $d f$ & $M$ & $t$-value & Sig \\
\hline Male & 12 & 34 & 43.19 & .361 & .007 \\
Female & 23 & & 48.04 & &
\end{tabular}

Table 3 shows the results of independent sample $t$-test to identify mean difference in male and female teachers' stress management techniques. Table values depict that the mean difference in stress management techniques of male $(M=$ 43.19) and female $(M=48.04)$ was statistically significant $t(34)=.361, \mathrm{p}=.007$. So, on the basis of these results research hypothesis that" there is significant difference between male and female head teachers' stress management techniques" is accepted and it is concluded that female head teachers use more stress management techniques than male head teachers.

Table 4: Independent Sample t-test to Identify Mean Difference in Head teachers' Stress Management Techniques Appointed in Rural and Urban Areas

\begin{tabular}{llllll}
\hline Variables & $N$ & $d f$ & $M$ & $t$-value & Sig \\
\hline Rural & 15 & 34 & 49.19 & .301 & .000 \\
Urban & 20 & & 41.04 & &
\end{tabular}

Table 4 shows the results of independent sample $t$-test to identify mean difference in head teachers' stress management techniques appointed in rural and urban areas. Table values show that the mean difference in the stress 
management techniques of head teachers appointed in rural areas $(M=49.19)$ and in urban Areas $(M=41.04)$ was statistically significant $t(34)=.301, p<.05$. So, on the basis of these results research hypothesis that" there is significant difference in head teachers' stress management techniques appointed in rural and urban areas" is accepted and it is concluded that head teachers working in rural areas use more stress management techniques than head teachers working in urban areas.

Table 5: ANOVA to Identify Mean Difference in Stress Management Techniques of Head teachers on the Basis of their Experience

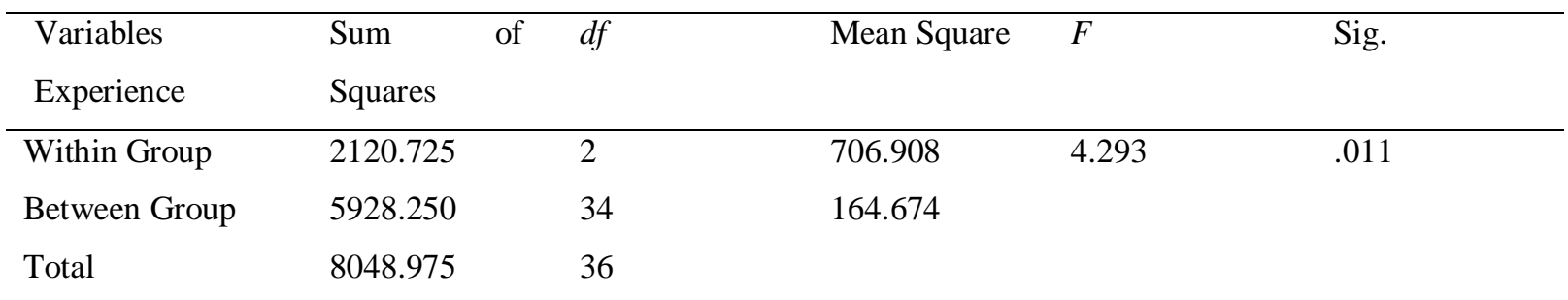

Table 5 is illustrating the results of ANOVA to identify mean difference in stress management techniques of head teachers on the basis of their experience. It is evident that mean difference is significant $F(2)=4.293, p<.05$ in stress management techniques of head teachers on the basis of their experience. On the basis of these results the research hypothesis that "there is significant difference in stress management techniques of head teachers on the basis of their experience" is accepted and it is concluded that head teachers with different job experience use different stress management techniques.

Table 6: ANOVA to Identify Mean Difference in Stress Management Techniques of Head teachers on the Basis of their Qualification

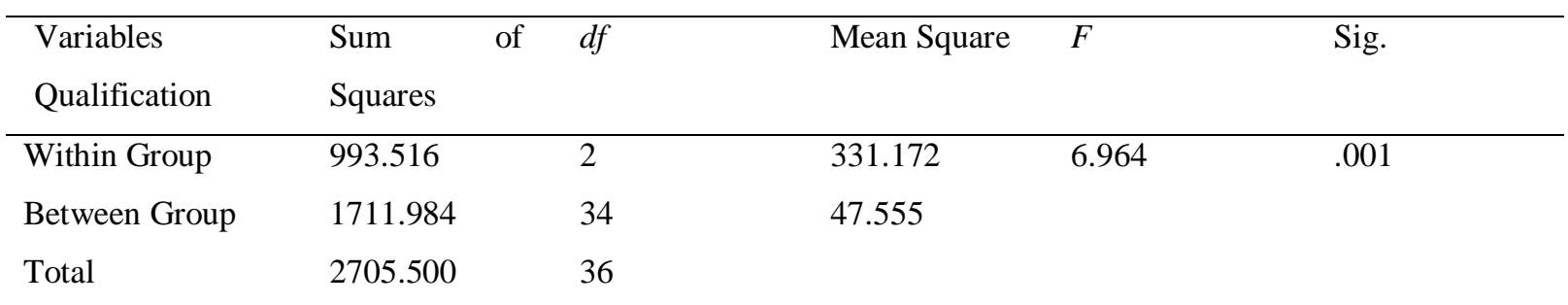

Table 6 is illustrating the results of ANOVA to identify mean difference in stress management techniques of head teachers on the basis of their qualification. It is evident that mean difference is significant $F(2)=4.293, p<.05$ in use of stress management techniques of head teachers on the basis of their qualification. On the basis of these results the research hypothesis that "there is significant difference in stress management techniques of head teachers on the basis of their qualification" is accepted and it is concluded that head teachers with different academic qualifications have different stress management techniques. Moreover, the head teachers having higher qualifications use more stress management techniques than other head teachers.

Table 7: ANOVA to identify Mean Difference in Stress Management Techniques of Head teachers on the basis of Districts

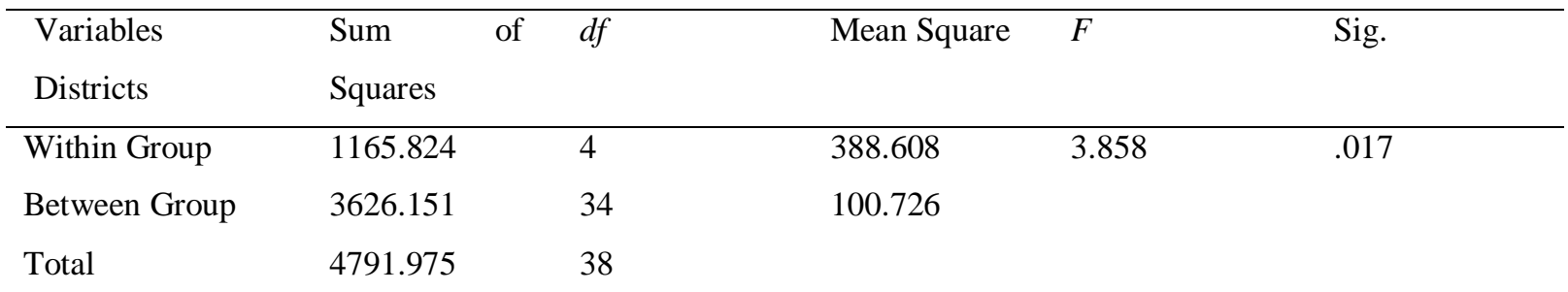

Table 7 is illustrating the results of ANOVA to identify mean difference in stress management techniques of head teachers on the basis of districts. It is evident that mean difference is significant $F(4)=3.858, p<.05$ in stress management techniques of head teachers on the basis of districts. On the basis of these results the research hypothesis 
that "there is significant difference in stress management techniques of head teachers on the basis of their districts" is accepted and it is concluded that head teachers serving in different districts use different stress management techniques.

\section{Findings and Conclusion}

Most of the head teachers told that they do catharsis when they are in stress. Majority heads do sharing with colleagues, family members, friends and some of them do share with their seniors. A number of heads told that they go for shopping and to their relatives in face of stress. Some of the heads go to watch movie, whereas majority of the heads told that they consult with their father/mother/elder. All of the heads except few told that they go to consult with a specialist in the field, whereas many consult with their friends and close relatives. Many heads were of the opinion that they become realistic in a stressful situation. Majority of the heads told that they set their future goals when they in stress. Few of the heads go to psychologist and follow psychologist's instructions to manage my stress. Many of the heads have to take medicine when they are unable to overcome stress. I go for outing when they are in stress. Many heads scold their juniors and subordinates in stress. All the heads except few offers prayers in stress while majority told that they ask others to pray for them when they are in stress. Few heads do exercise when they are in stress. A number of heads responded that they go for some enjoyment in case of stress. Many of them use relaxing techniques and use to breathe deeply to relax themselves when they feel stressed. Majority of the heads like to sleep quietly when they stressed and most of them watch their favorite TV program when in stressed situation. Majority heads told that they leave everything on Allah when they cannot manage their stress. Few of the heads use to weep to manage their stress. Majority heads responded they try to find out the reasons of stress to control it. Many of the heads told they they try to find out their mistakes when they feel stress. Few heads always accept their fault to manage stress. There were only few heads who write diary and read books to manage their stress.

The identified stress management techniques for the school administrators and the head teachers may help the ministry, departments and agencies responsible for developing training for the head teachers of schools (school administrators) to have a point of reference in preparing the training and professional development programs. In doing so, the programs will be effective since they would meet the needs of school head teachers to give training on stress management techniques so as to improve the school performance. With effective stress management techniques that will be attained by the school head teachers, outstanding students' academic performance at the school and national level can be attained.

\section{Recommendations}

Following recommendations are made:

- There is a need to introduce training sessions regarding stress management techniques for the head teachers of Punjab.

- There should be a proper allocation of budget for head teachers' stress management trainings.

- Stressors need to be eradicated at all levels. For this purpose, procedures and rules need to be implemented and monitored effectively.

- Head teachers should be motivated through financial and other social benefits. So, that financial stress factors may be controlled.

- There must be some recreational programs for head teachers in order to control their anxiety.

- There should be a mechanism to help out the newly selected head teachers by the senior head teachers at their tehsil and district level.

Numerous stress reduction programs and policies have been proven to be helpful to reduce head teachers' stress, improve their well-being and enhance students' outcomes, and ultimately reduce financial burden on schools and state. These programs include: "Mentoring and Induction Programs for Beginning Head teachers" which can increase head teachers' level of satisfaction and rate of retention, which will culminate into enhanced student academic achievement. "Workplace Wellness Programs" have been proved to reduce "health risk", "health care costs", and "head teacher absenteeism". "Social Emotional Learning" programs have improved "students' behavior" which also help to reduce head teachers stress and head teacher may engage positively with their teachers and students. "Organization Individual Interface" is a "Mindfulness/stress management program" which can help head teachers in 
developing coping skills and awareness to decrease "anxiety", "depression", and "improved health". At organizational level especially there is a dire need to reduce the head teacher stress, for this purpose basic research is required to find out context specific ways to manage head teacher stress and support them in improving their health and well-being, to avoid negative outcomes that negatively impact, students, teachers, parents, , school systems and communities ultimately.

\section{References}

Chan, D. W. (1998). Stress, coping strategies, and psychological distress among secondary school teachers in Hong Kong. American Educational Research Journal, 35(1), 145-163.

Cohen, J. (1988). Statistical power analysis for the behavioral sciences (2nd edition). Hillsdale, NJ: Erlbaum.

Derogatis, L. R. (1987). The Derogatis stress profile (DSP): Quantification of psychological stress. Adv. Psychosom. Med., 17, 30-54.

Fern, E. F., \& Monroe, K. B. (1996). Effect-size estimates: Issues and problems. Journal of Consumer Research, 23, 89-105.

Goleman, D. (1995). Emotional intelligence. New York: Bantam Books.

Guglielmi, R. S., \&Tatrow, K. (1998). Occupational stress, burnout, and health in teachers: A methodological and theoretical analysis. Review of Educational Research, 68(1), 61-99.

Hedges, L. V., \&Olkin, I. (1985). Statistical methods for meta-analysis. San Diego CA: Academic Press.

Houston, B. K., \&Vavak, C. R. (1991). Hostility: Developmental factors, psychological correlates, and health behaviors. Health Psychology, 10, 9 - 17.

Hunter, J. E., \& Schmidt, F. L. (1990). Methods of meta-analysis. New York: Russel Sage. 28

Kobasa, S. C., Maddi, J., Ouccelli, M., \& Zola, M. C. (1985). Effectiveness of hardiness, exercise and social support as resources against illness. Journal of Psychosomatic Research, 29, 525-533.

Kyriacou, C. (2001). Teacher stress: Directions for future research. Educational Review, 53(1), 27-35.

Lazarus, R. S. (1966). Psychological stress and the coping process. New York: McGraw- Hill Book Company.

Lazarus, R. S., \&Folkman, S. (1984). Stress, appraisal, and coping. New York: Springer.

Lipsey, M. W., \& Wilson, D. B. (2001).Practical meta-analysis. Thousand Oaks, CA: Sage.

Maslach, C., \& Jackson, S. E. (1981).The measurement of experienced burnout. Journal of Occupational Behavior, 2 , 99-113.

Scheier, M. F., \& Carver, C. S. (1985). Optimism, coping and health: Assessment and implications of generalized outcome expectancies. Health Psychology, 4, 219- 247.

Vandenberghe, R., \&Huberman, A. M. (Eds.). (1999). Understanding and preventing teacher burnout: A sourcebook of international research and practice. Cambridge, UK: Cambridge University Press.

Watson, D., \& Clark, L A. (1984). Negative affectivity: The disposition to experience-aversive emotional states. Psychological Bulletin, 96, 465-490.

Kasper, D.L. (2015). Harrison's Principles of Internal Medicine, 19th Ed. United States: McGraw-Hill Education. 


\section{Questionnaire}

\section{Demographic Information about the Respondents}

Gender: Male/Female

Area: Rural /Urban

School

District

Experience

\section{Qualification}

\section{Designation}

\section{Age(in years): 18-22, 23-27, 28-32, 33-37, above 38}

Instructions: Please read each sentence carefully and put a checkmark on appropriate response.

Strongly agree $=$ SA, Agree $=$ A, Undecided $=$ UD, Disagree $=$ D and Strongly Disagree $=$ SD

\begin{tabular}{|c|c|c|c|c|c|c|}
\hline S.No. & Statements & SD & $\mathbf{D}$ & UD & A & $\mathbf{S A}$ \\
\hline \multicolumn{7}{|c|}{ Sharing } \\
\hline 1. & When I am in stress I catharsis & & & & & \\
\hline 2. & If I feel stress I share with my colleagues & & & & & \\
\hline 3. & $\begin{array}{l}\text { When I am in stress I share with my family } \\
\text { members }\end{array}$ & & & & & \\
\hline 4. & When I am in stress I share with my friends & & & & & \\
\hline 5. & $\begin{array}{l}\text { When I am in stress I take help from my } \\
\text { seniors }\end{array}$ & & & & & \\
\hline \multicolumn{7}{|c|}{ Recreation } \\
\hline 6. & When I am in stress I go for shopping & & & & & \\
\hline 7. & When I am in stress I go to my relatives & & & & & \\
\hline 8. & When I am in stress I go to watch movie & & & & & \\
\hline 9. & $\begin{array}{l}\text { When I am in stress I consult with my } \\
\text { father/mother/elder }\end{array}$ & & & & & \\
\hline 10. & $\begin{array}{l}\text { When I am in stress I go to consult } \\
\text { specialist in the field }\end{array}$ & & & & & \\
\hline 11. & $\begin{array}{l}\text { When I am in stress I consult with my } \\
\text { friends }\end{array}$ & & & & & \\
\hline \multicolumn{7}{|c|}{ Consultancy } \\
\hline 12. & When I am in stress I consult with my & & & & & \\
\hline 13. & In stress a become realistic & & & & & \\
\hline 14. & I set my goals in future when I am in stress & & & & & \\
\hline 15. & I go to psychologist when I am in stress & & & & & \\
\hline 16. & $\begin{array}{l}\text { I follow psychologist's instructions to } \\
\text { manage my stress }\end{array}$ & & & & & \\
\hline 17. & I take medicine when I am unable to & & & & & \\
\hline
\end{tabular}




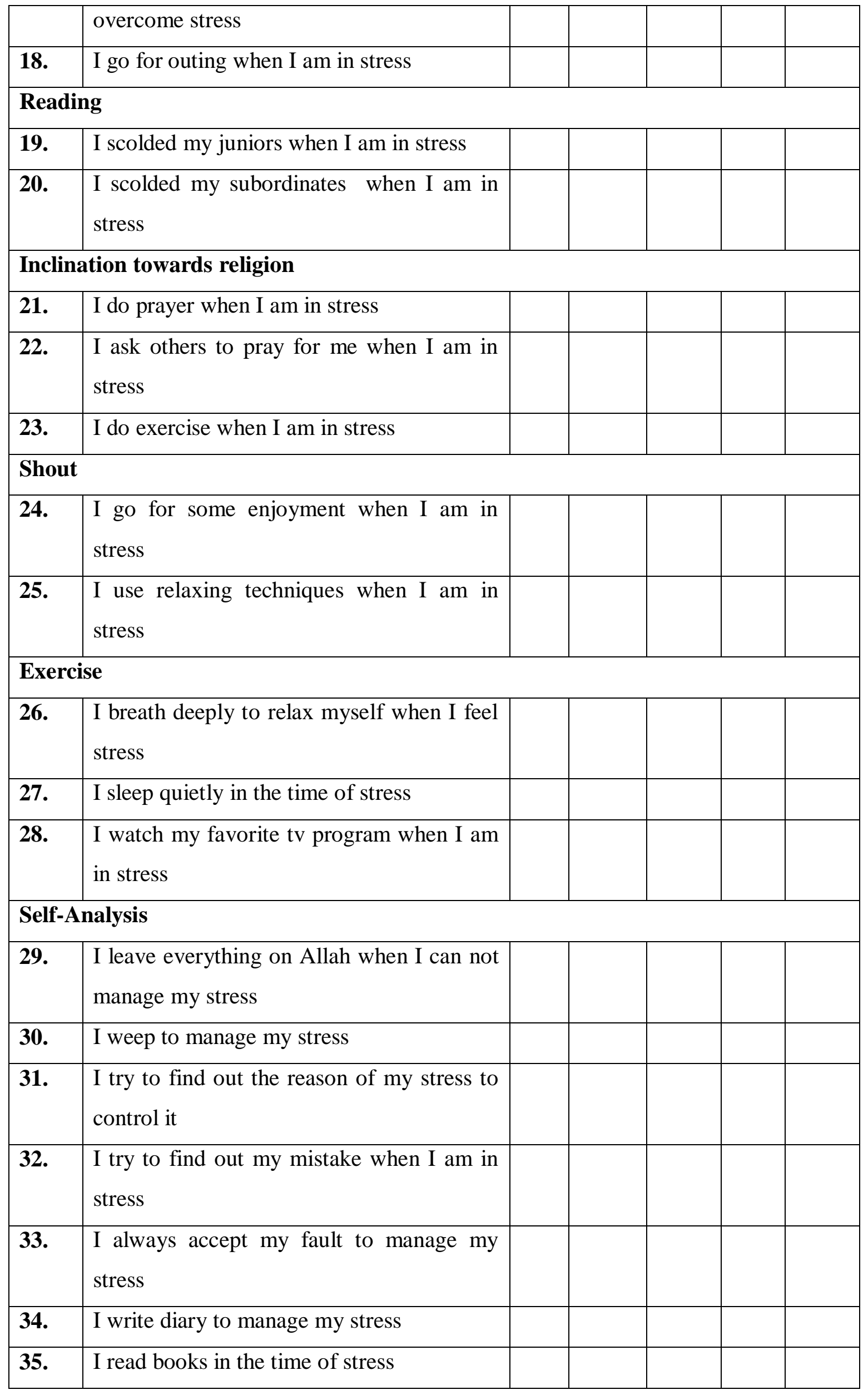

